\title{
Comparative law at a crossroads
}

\author{
by Esin Örücü
}

\begin{abstract}
A book which seeks to bring a fresh approach to many of the issues in comparative law was launched last December at the IALS. The author, a co-editor of Comparative Law: A Handbook, explains what the new volume is seeking to achieve.
\end{abstract}

$\mathrm{C}$ omparative law has been the domain of private lawyers for a very long time and, to a large extent, it still is. The substantive areas covered are traditional private law topics such as obligations and contract. The methodological tool for comparison is functionalism, which is the search for functional equivalents, the emphasis being on similarities between the legal systems studied. In "common core" studies leading to the formulation of European principles in a number of areas of private law, this methodological tool is still widely in use today. The legal systems studied are nearly always those of the western world, and in fact only the most prominent ones, other areas of the world being left to the care of "regionalists." Traditional introductory works cover first the definition, aims, purposes, uses and methodology of the subject and then introduce the reader to the socalled "major" prominent legal families and legal systems. This remained the practice from 1900, the date of the major comparative law event, the Paris Congress, until the end of the twentieth century. Even today, in the context of the European Union, the main comparisons are between the common law and the civil law "legal families" and institutions therein.

As a result, in the last decade, comparative law has been widely criticised for lacking in theory and being Eurocentric, black-letter-law and private law oriented. The criticism comes mainly from legal theorists of various shades, sociologists of law, anthropologists of law and some comparatists who are not necessarily private lawyers, but who are interested in law and society and do not regard comparative law solely as a tool for the practice of law. There are still those who see merit in the study of normative rules alone, alongside those who believe that law can only be studied in context to be meaningful. Research into culture, tradition, identity, distinctiveness, difference and legal pluralism compete with mainstream comparative black-letter-law research. Comparative law is indeed at a crossroads.
During this past decade we have witnessed increasing interest in all forms of comparative law, international law and transnational law. The character, quality and quantity of work have increased and changed, but the basic problems have remained the same. There is no one definition of what comparative law and comparative method are. However, the emphasis has shifted from concern with justifying the practical utility of the subject and avoiding superficiality, to regarding comparative law as a big tent covering a number of different kinds of scholarship.

\section{NEED FOR A FRESH APPROACH}

In the belief that times have changed, that many topics other than those of classical private law are of crucial importance today, and that we are in need of a fresh approach to many of the issues of comparative law (some dealt with before and some not), we ventured into the production of a new volume, Comparative Law: A Handbook, with the main aim of bringing to the reader an awareness of what is happening to comparative law in our day. The first decision to be made was what title the volume should have: "Comparative Law" or "Comparative Legal Studies"? Considering that most courses on offer in our universities are comparative law courses and that the term is well established and therefore would be easily recognisable, we opted for "Comparative Law".

Our purpose is to fill the gap in comparative law teaching and study, and to familiarise the reader not only with the classical material, but also with new material and the current and controversial issues of comparative law and comparative legal studies, which is now regarded by many as a more acceptable title for the discipline.

Generally in discourse, some controversies can be diachronic, they develop incrementally and may in time lead to an understanding. Some controversies can be dialectic, and through thesis, antithesis and synthesis, a point can be reached which may be a new thesis as a new 
starting point. In comparative law discourse however, controversies, and there are many, appear simultaneously. This was the case in earlier years and is still the case today. Controversies of comparative law are synchronic, never ending, never totally resolved, ever-multiplying. This is why I call comparative law an enigma full of controversies and paradoxes.

The controversies of comparative law start with the name (comparative law/ comparative legal studies) and continue with the subject (it does not exist/it is the most sophisticated branch of social science), the content (merely a method/the only approach to law), the method (there is only one: either functionalism or contextualism /there are many on a sliding scale), and end in the issues discussed: legal families ("civil law + common law $=$ the world"/mixed systems/extra-ordinary places); convergence/divergence (stressing either similarities or differences); translate/do not translate; transplant (transposition/transplants are impossible); normative inquiries/ cultural immersion; common core/ better law; private law/public law; and metaphors (they are useful / they are misleading and an apology for lack of theory).

Comparative Law: A Handbook, edited by David Nelken, a sociologist of law, and myself, a generalist comparatist, commences with a general introduction to comparative law and comparative legal studies and a critical overview with a detailed signalling system binding the book together. It then moves on to contemporary and burgeoning areas of comparative law such as the convergence/non-convergence debate, law in context (culture and economics), cultural distinctiveness and diversity, globalism versus localism, legal families and mixed systems, competition between legal systems, looking beyond the western world, the use of comparative law by judges, the role of comparative law in law reform activities and harmonisation, public law comparisons in both constitutional law and administrative law, a new common law in human rights, the "common core" and the "better law" approaches, comparative law for international criminal justice, commercial law and family law, and a comparative law research project.

The volume consists of three parts: Comparative law at a crossroads, new directions for comparative law and new territories for comparative law. Some chapter headings tell of the slant of the volume: Com-paring; Defining and using the concept of legal culture; Is it so bad to be different?: Comparative law and appreciation of diversity; Globalisation and comparative law; Beyond Europe; Convergence of private law in Europe: towards a new ius commune?; Comparative family law: moving with the times?; Comparative commercial Law: rules or context?

The chapters are contributed by Masha Antokolskaia, John Bell, Roger Cotterrell, Sjef van Erp, Nicholas Foster, Patrick Glenn, Andrew Harding, Peter Leyland, Christopher McCrudden, Werner Menski, David Nelken,
Anthony Ogus, Esin Örücü, Paul Roberts, Jan Smits and William Twining.

A number of other topics, some theoretical such as the post-modern critique of comparative law; theories about peoples' practices and of different groups of actors of the law; and beyond legal rules, and some substantive topics such as alternative dispute resolution, e-commerce, environmental law, bio-ethics or food safety could have been selected. But choices had to be made. The topics we selected had either been hitherto neglected or had not been considered in any standard comparative law textbook. We decided on an innovative approach. Each chapter starts with a list of key concepts. There are questions for discussion and a reading list of works referred to in the chapter and additional reading at the end of the chapters. Most chapters include useful website references.

On December 6, 2007 the book was launched and a discussion was held in the Institute of Advanced Legal Studies, followed by a question, comment and answer period. Professor John Flood, University of Westminster, and Emeritus Professor Gordon Woodman, University of Birmingham, kindly agreed to reply to the introduction by David Nelken and myself.

\section{ISSUES RAISED IN DISCUSSION}

Various issues were raised by our discussants and our audience: What is the difference between comparative law and comparative legal studies? Are we comparatists or comparativists? What makes a comparatist? How is comparative law knowledge acquired? Does going beyond Europe actually enlarge our understanding of aspects of law? Should one take a narrow approach and start with a study of a part of a particular legal system before looking at other jurisdictions, and is this the only path for gaining precision? Should all generalisations stem from comparisons? Can one effectively theorise without working through examples? Is explanation of differences the real aim of comparative law research? When is similarity relevant? How far can comparatists recognise and develop the concept of legal pluralism? How can co-existing laws and their interrelationships be analysed? Can disorder be ordered? Can one actually categorise laws? Can one explain the laws of one people in terms of the laws of another people, especially by utilising solely western legal concepts? Having mastered one's own law, should one live in another counrtry for a while, study the law there, become totally acquainted with the legal environment, and only then proclaim to have become a comparatist?

There was also some scepticism concerning the functions of comparative law. However, it was pointed out that all lawyers are comparatists by necessity, whether they think of themselves as such or not, since a lawyer can no longer deal only with his/her own legal system in isolation.

Other questions raised were related to what the book was aiming at. Did it lay down limitations? Was it 
coherent? Suggestions were made for a second edition to include more chapters on examples of empirical research, increase the number of contributions with a less occidental slant and more on legal pluralism as well as legal comparative anthropology, and cover more of the new and growing topics.

It is only through such discussion that comparative law can reach maturity. However, at this crossroads the present generation of comparatists have to think again. How far should they engage with other disciplines? If comparative lawyers cannot work alone, then should they replace or supplement legal, historical and philosophical approaches with concepts and methods taken now from political science, economics, sociology, anthropology, or even business studies, geography, literary theory or psychology? How can we as comparatists, assist the growth of a new generation of comparatists? What can we offer them?

We know that by looking at the world of law and the environment in which it lives, comparative law can provide knowledge about "law as rules", "law in context", and "law as culture" thus enabling the comparatist to have comprehensive and in depth knowledge of the legal phenomena and their interaction in society. Comparative law, by drawing from the pool of models to illustrate the general points it is making, can bring additional perspectives to aid our understanding of the world of law and society. Only thus would a continuous desire to look for comparative inspiration be fostered.

We can also talk of comparative family law, comparative contract law or comparative constitutional law where the term "comparative" indicates a way of looking at an area of law. In this sense, the scope of the comparative approach is becoming increasingly significant as more and more lecturers and domestic lawyers consider this approach, though not labelling themselves as comparatists. In addition, most $\mathrm{PhD}$ theses contain elements of the comparative approach though they are not "comparative law" theses.

Then of course we can regard comparative law as a tool of interpretation for judges in reaching solutions and for lawyers pleading cases. The value of this tool is now being appreciated and accepted in our courts, though often at the level of providing inspiration and lessons. Maybe the most important and true mission of comparative law and comparative legal studies is to inspire the curious mind, ever searching to understand more.

\section{Esin Örücü}

Honorary Senior Research Fellow and Professor Emerita of Comparative Law, University of Glasgow and Professor Emerita of Comparative Law, Erasmus Universiteit Rotterdam 